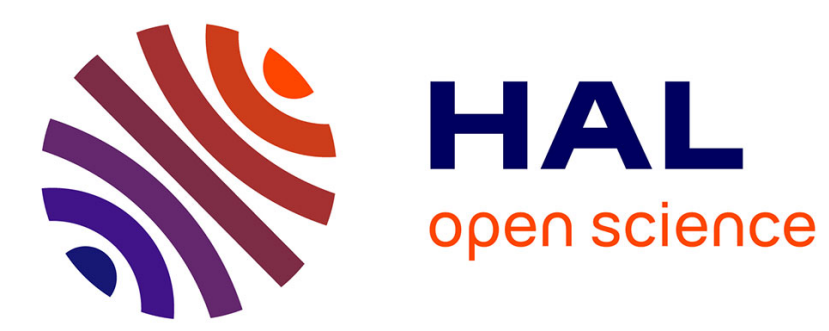

\title{
Ecological assessment of Phragmites australis wetlands using multi-season SPOT-5 scenes
}

Brigitte Poulin, Aurélie Davranche, Gaëtan Lefebvre

\section{To cite this version:}

Brigitte Poulin, Aurélie Davranche, Gaëtan Lefebvre. Ecological assessment of Phragmites australis wetlands using multi-season SPOT-5 scenes. Remote Sensing of Environment, 2010, 114 (7), pp.16021609. 10.1016/j.rse.2010.02.014 . hal-00692539

\section{HAL Id: hal-00692539 \\ https://hal.science/hal-00692539}

Submitted on 16 May 2012

HAL is a multi-disciplinary open access archive for the deposit and dissemination of scientific research documents, whether they are published or not. The documents may come from teaching and research institutions in France or abroad, or from public or private research centers.
L'archive ouverte pluridisciplinaire HAL, est destinée au dépôt et à la diffusion de documents scientifiques de niveau recherche, publiés ou non, émanant des établissements d'enseignement et de recherche français ou étrangers, des laboratoires publics ou privés. 
2 Ecological assessment of Phragmites australis wetlands using multi-season 3 SPOT-5 scenes

6 Brigitte Poulin ${ }^{1}$, Aurélie Davranche ${ }^{1,2}$ and Gaëtan Lefebvre ${ }^{1}$.

$7 \quad{ }^{1}$ Tour du Valat Research Center, Le Sambuc, 13200 Arles, France

8 Institut für Geographie, Friedrich-Alexander Universität Erlangen-Nürnberg, Kochstraße 4/4, 991054 Erlangen, Germany

10

11

12

13

14

15

16

17 Running title : Wetland ecological assessment

18 Word count : $\mathbf{6 5 9 4}$

19

22 *Corresponding author: Tel: +33 (0) 4909729 58, FAX +33 (0) 490972019

23 E-mail address: poulin@,tourduvalat.org

24 
28 Ecologists and conservationists need accurate and replicable tools for monitoring wetland

29 conditions in order to develop and implement adaptive management strategies efficiently. The

30 Rhone Delta (Camargue) in southern France encloses 9200 ha of fragmented reed marshes

31 actively managed for reed harvesting, waterfowl hunting or cattle grazing, and holding significant

32 numbers of vulnerable European birds. We used multi-season SPOT-5 data in conjunction with

33 ground survey to assess the predictive power of satellite imagery in modelling indicators of reed

34 structure (height, diameter, density and cover of green/dry stems) relevant to ecosystem

35 management and bird ecology. All indicators could be predicted accurately with a combination of

36 bands (SWIR, NIR) and indices (SAVI, OSAVI, NDWI, DVI, DVW, MSI) issued from scenes of

37 March, June, July, September or December and subtraction between these. All models were

38 robust when validated with an independent set of satellite and field data. The high spatial

39 resolution of SPOT-5 scenes (pixel of $10 \times 10 \mathrm{~m}$ ) permits the monitoring of detailed attributes

40 characterizing the reed ecosystem across a large spatial extent, providing a scientifically-based,

41 replicable tool for managers, stakeholders and decision-makers to follow wetland conditions in

42 the short and long-term. Combined with models on the ecological requirements of vulnerable bird

43 species, these tools can provide maps of potential species ranges at spatial extents that are

44 relevant to ecosystem functioning and bird populations.

45

46 KEY-WORDS: Camargue, ecosystem health; GLM modelling; multispectral indices; multitemporal

47 imagery; Phragmites australis; vegetation structure, SPOT-5 satellite; state indicators; wetland 48 monitoring. 


\section{1}

\section{Introduction}

(n)

Although wetlands support high biodiversity and provide an extensive range of public goods and services to humankind, they are among the most threatened habitats in the world (Williams, 1993; Dudgeon et al., 2006). Their high rate of disappearance has prompted the development of remotely-sensed techniques for mapping their distribution, but little has been done for monitoring their state of health, especially at extensive spatial extents that are relevant to ecosystem functioning and species populations. Ecologists and conservationists need accurate and replicable tools for monitoring wetland conditions in order to develop and implement adaptive-management strategies efficiently (Ostendorp et al., 1995; Kerr \& Ostrovsky, 2003). Common reed Phragmites australis (Cav. Trin. ex Steudel) is the most widely distributed flowering plant on earth (Marks et al., 1994; Güsewell \& Klötzli, 2000). It typically grows in or near freshwater, brackish, and alkaline wetlands along a gradient from deep water $(>2 \mathrm{~m})$ to terrestrial $(<1 \mathrm{~m}$ below substrate) conditions (Clevering, 1998). It often dominates the area it occupies to form dense stands in floodplains, lowland shallow lakes and along natural river channels or irrigation canals. Reed stands are considered as undesirable invaders in some areas of North America where non-endemic genotypes are proliferating, but have high conservation and socio-economic value throughout in Europe due to specific vulnerable bird species and various traditional, recreational and commercial activities (Güsewell \& Klötzli, 2000; Ludwig et al., 2003; Valkamaa et al., 2008).

Common reed can resist fire, frost, high $\mathrm{pH}$, water deficit and salt, but has a low tolerance for wave and current action (Marks et al., 1994; Pagter et al., 2005). Each spring, annual shoots emerge from perennial underground rhizomes, growing up to 3-4 m tall in optimal conditions.

These vertical stems produce leaves, flower, and eventually set seed. The stems die in early 
winter but stand as rigid canes for several months (Burgess \& Evans, 1989). Density may reach 200 (wet stands) or 300 (dry stands) shoots per meter square (Hara et al., 1993), leading to a rapid accumulation of decaying matter, which contributes to drying out of the reedbed that eventually evolves towards scrub and woodland (Granéli, 1989; Cowie et al., 1992). Common reed is relatively intolerant of summer mowing and cattle grazing (van Deursen \& Drost, 1990), but cutting or burning the dry stems in winter will slow down this hydroseral process (Burgess \& Evans, 1989; Bedford, 2005). Common reed can tolerate a constant salinity of up to $22.5 \mathrm{~g} / \mathrm{L}$, but shoot height, diameter and density will start decreasing above $5 \mathrm{~g} / \mathrm{L}$ (Lissner \& Schierup, 1997). Decreased reed density and height also result from water deficit (Engloner, 2009). Optimal conditions for reed growth are freshwater bodies exhibiting a seasonal fluctuations of $30-\mathrm{cm}$ in water levels (Deegan et al., 2007). A vigourous reedbed will have homogeneous vegetation cover, tall green stems and a 2:1 ratio of dry to green stems. Permanent flooding without water renewal will result in lower shoots, a higher dry-to-green-stem ratio, and eventually a clumpy distribution of reeds following the death of rhizome buds and roots (Armstrong et al., 1996). Winter burning or cutting will have a positive impact on shoot density and diameter, while reducing shoot height and increasing plant richness the next spring (Granéli, 1989; Cowie et al., 1992). A recent review of the factors influencing reed structure, growth and biomass is provided by Engloner (2009).

Habitat selection by breeding birds is tightly related to structural components of the reed ecosystem throughout Europe (Leisler et al., 1989; Boar, 1992; Jedraszko-Dabrowska, 1992; Graveland, 1999; Martinez-Vilalta et al., 2002; Gilbert et al., 2005; Polak et al., 2008).

5 Ecological requirements of reed bird species in southern France have been well identified 6 (Barbraud et al., 2002; Poulin \& Lefebvre, 2002; Poulin et al., 2002; 2005; 2009): the great reed 7 warbler (GRW) Acrocephalus arundinaceus breeds in harvested or non-harvested reedbeds 
where shoot diameter is above $6 \mathrm{~mm}$ (or $195 \mathrm{~cm}$ in height); the moustached warbler (MW) $A$.

99 melanopogon prefers areas with a high proportion of stems with flower head (one-year old reed)

100 intermingled with other emergent plants; the bearded tit (BT) Panurus biarmicus is most

101 abundant in reedbeds having high densities of dry and thin shoots, which often reflects a stress

102 response to permanent flooding; the colonial purple heron (PH) Ardea purpurea nests in flooded

103 reedbeds having tall and thick shoots with a 2:1 dry:green stem ratio; the Eurasian bittern (EB)

104 Botaurus stellaris is either found in harvested areas (no dry stems) with homogeneous vegetation

105 cover or in non-harvested reedbeds characterized by numerous small open-water areas used for

106 foraging, both including small patches of reed cut two winters ago (1:1 dry:green stem ratio).

107 The Rhone delta (Camargue) in southern France encompasses 145000 ha including 9200

108 ha of reed marshes that are actively water managed for various socio-economic uses (Mathevet et

109 al., 2007). These marshes enclose over 50\% of the French population of three vulnerable reed

110 birds in Europe: the moustached warbler, the purple heron and the Eurasian bittern. Conflicts

111 over water management among users, the presence of salt in the water table together with the

112 foreseen impacts of climate change justify the development of replicable and robust tools for

113 monitoring the state of health of these reedbeds. Remote sensing appeared as the most

114 appropriate approach for monitoring this quasi monospecific and fragmented habitat spread over

115 a large area and partially located on private properties with difficult access (Davranche et al.,

116 2009b). In this study, we used multispectral and multi-seasonal data in conjunction with ground

117 surveys to assess the predictive power of SPOT-5 scenes in modelling reedbed features that are

118 relevant to bird ecological requirements and management practices. The ultimate goal is to

119 produce replicable maps of reed-stand conditions to orient management and conservation actions

120 over the long term.

121 


\section{Methods}

123

\subsection{Study area} lagoon, river, canal), size (from $<1$ to $>2000$ ha), hydrology (permanent or temporary flooding with stable or fluctuating water levels) and underground salinity (from 0.5 to $30 \mathrm{~g} / \mathrm{L}$ ). Spatial

129 distribution of reedbeds was previously assessed with SPOT-5 scenes and field data using a

130 binary classification-tree algorithm (Fig. 1). The resulting maps for two successive years lead to

131 an overall accuracy of $99 \%$ and $98 \%$ respectively (Davranche et al., 2009b). Water levels in

132 most of these reedbeds are managed to improve yield of socio-economic activities such as

133 waterfowl hunting, winter-reed cutting, cattle grazing, fishing and nature conservation (Mathevet

134 et al., 2007). For instance, harvested reedbeds are typically flooded during the growing season

135 (March to June) and drained in winter to facilitate access and reduce impact of cutting engines on

136 the rhizomes, whereas hunting marshes are permanently flooded or drained in spring only. These

137 activities have a direct impact on reed structure through the creation of open-water areas for

138 hunting (by cattle grazing or removal of the rhizomes) and the withdrawing of dry stems by

139 cutting. They also affect reed structure indirectly through water management which, combined

140 with rainfall and the presence of salt in the water table, will affect reed growth and the overall

141 state of health of the plant formation. The climate is Mediterranean with mild and windy winters

142 and hot and dry summers. Mean annual rainfall over the last 30 years is $579 \pm 158$ (SD) mm,

143 being concentrated in spring and autumn, with large intra- and inter-annual variations

144 (Chauvelon, 2009). Total rainfall was 664 and $411 \mathrm{~mm}$ in 2005 and 2006, respectively. 


\subsection{Indicators of reed condition}

Hawke \& José (1996) have suggested four indicators of reedbed health: height, diameter, and density of reed along with presence of shrubs. We have selected five additional criteria easily measurable in the field that are indicative of stand condition and associated with ecological requirements of birds and reed harvesters (Table 1). Height and diameter of green stems, as well as density of flower heads, can vary on a yearly basis and are tightly related to hydrological conditions (fluctuations in water levels and salinity). Density of reeds and the ratio of dry-togreen reeds are also affected by hydrology, but more directly by management practices such as reed cutting, burning or grazing. Low and high reed density can both reflect ecosystem degradation and this parameter must be interpreted along with reed height or diameter for condition assessment. Reed-cover homogeneity and scrub encroachment are indicative of a degraded reedbed evolving towards open water or woodland, respectively. Two of these criteria, plant richness and shrub encroachment, could not be predicted in this study following their low levels in our study area.

\subsection{Field data}

Water and vegetation measurements were taken in June and July at 39 reedbed sites (training sample) in 2005 and 21 sites (validation sample) in 2006 (Fig.1). Selection of study sites resulted in a compromise between admittance, accessibility, and getting a representative sample of reedbeds based on aerial photographs and videos collected during aerial surveys. At each site, one sampling plot of $20 \times 20 \mathrm{~m}$ corresponding to four pixels of a SPOT-5 scene was located within a homogeneous area representative of a larger zone and located at least $70 \mathrm{~m}$ from the 
170 border to reduce edge effects in spectral responses. Sampling plots were geolocated with a GPS

171 (Holux GR-230XX) of 2-5 m accuracy using the average value obtained from the centre of the

172 plot at three meters above ground to limit the echo caused by tall reeds. Water level, plant cover

173 and floristic composition were estimated along two diagonals $28-\mathrm{m}$ long crossing the entire plot.

174 Water levels were systematically estimated with a rule every $4 \mathrm{~m}$ along each diagonal and in the

175 centre of the plot $(N=17)$. We recorded whether this measure was taken above reeds or bare

176 ground and used the proportion of readings taken in reeds as a degree of reed-cover homogeneity.

177 This distinction was not made in 2006, hence we used half the 2005 plots for the training sample

178 and applied the other half on the 2006 scenes for model validation, assuming that this

179 environmental parameter varied little over one year. Reed density, height and diameter were

180 measured within four quadrats of 50 X $50 \mathrm{~cm}$ per plot located at seven meters from the centre of

181 the plot in each cardinal direction. Reed density corresponds to the total number of green and dry

182 stems inside the quadrat. Among dry reeds, we distinguished whole stems with flower heads

183 (one-year reed) from flowerless or broken stalks. Whole stems with or without flowers were

184 aggregated during the 2006 field survey, hence we used half the 2005 data for validation on the

1852005 scenes. Reed height and diameter were measured on two green and four dry 'average' stems

186 inside the quadrats on both years.

187

$188 \quad 2.4$ SPOT-5 data

189

SPOT-5 scenes centred on the Rhone delta were acquired on 30 December 2004, 17 March,

19119 May, 18 June, 31 July and 21 September 2005 through the SPOT Image Programming Service

192 (Copyright CNES). These periods were selected based on key events in the phenology and water

193 management of reedbeds (Davranche et al., 2009b). For model validation, we used images from 
18 December 2005, 16 March, 29 May, 23 June, 24 July and 15 October 2006, as no scene was

195 available in September. SPOT-5 scenes have 10-m pixel resolution and four spectral bands: B1

196 (green: 0.50-0.59 $\mu \mathrm{m}$ ), B2 (red: 0.61-0.68 $\mu \mathrm{m}$ ), B3 (near infrared NIR: 0.79-0.89 $\mu \mathrm{m}$ ) and B4

197 (short-wave infrared SWIR: 1.58-1.75 $\mu \mathrm{m}$ ). Radiometric corrections were performed using, the

198 Second Simulation of the Satellite Signal in the Solar Spectrum (6S), developed by Vermote et al.

199 (1997). This atmospheric model predicts the sensor signal assuming cloudless atmosphere, taking

200 into account the main atmospheric effects (gaseous absorption by water vapour, carbon dioxide,

201 oxygen and ozone; scattering by molecules and aerosols) and lead to a mean error of $0.7 \%$ per

202 band (Davranche et al., 2009a). The corrected scenes were projected to Lambert conformal conic

203 projection datum NTF (Nouvelle Triangulation Française) using a second-order transformation

204 and nearest-neighbour re-sampling (Davranche et al., 2009a), and georeferenced to a topographic

205 map at 1:25 000 scale using ground control points (RMSE $<$ one pixel). Mean reflectance values

206 at the locations of the field plots were extracted for each band using the 'Spatial Analyst' of

207 ArcGIS version 9.2 (Environmental Systems Research Institute). Eleven multispectral indices

208 among the most commonly found in the literature (Table 2) were calculated for each scene, as

209 well as multitemporal indices obtained by subtracting two monthly values from a same indice.

\subsection{Model calibration and validation}

213 The six scenes provided 15 possible combinations of subtractions between two dates and

214 yielded 315 explanatory variables when multiplied by the four bands and 11 indices. A pre-

215 selection of conceptually meaningful explanatory variables based on environmental resilience of

216 reeds was made based on the following assumptions: (1) under similar abiotic conditions, reed

217 parameters should not vary annually and the remotely-sensed data useful for describing these 
218 parameters should have a similar constancy; (2) reed parameters are mostly influenced by human

219 intervention, which is site specific and unlikely to affect distinctly a large number of marshes on

220 a given year. We compared the degree of relationships $\left(R^{2}\right)$ and the mean value ( $t$-test) of each

221 predictive variable from the 39 study plots in 2005 and 2006, and conservatively used $P>0.01$ as

222 threshold value for variable selection with both tests.

We built Generalized Regression Models with a forward-stepwise procedure in Statistica

224 version 8.0 (StatSoft Inc.) to predict reed parameters from the remotely-sensed data. For each

225 computed model, the regression analysis was rerun excluding any selected variable, one by one,

226 to verify that model fit was not improved when the variables selected automatically were

227 replaced by two or more other variables. Goodness-of-fit of the model was assessed by

228 calculating the coefficient of determination $\left(R^{2}\right)$ and the normalized root-mean-square error

229 (NRMSE) between the predicted and observed 2005 values (training sample). Predictive

230 accuracy of the model was assessed by calculating $R^{2}$ and NRMSE between the predicted and

231 observed 2006 values when applying the 2005 model. This validation approach, based on a

232 dataset independent from the training sample, is considered as the most compelling

233 demonstration of model usefulness (Mac Nally \& Fleishman, 2004; Thomson et al., 2007).

234 Means of predicted and observed values from the validation sample were further compared using

235 Student's $t$-tests (or Welch's t-test if unequal variances) to determine whether field calibration

236 would be required in future model application. 


\section{Results}

3.1 Pre-selection of predictive variables

Fifty-three variables did not differ significantly between 2005 and 2006 and were selected

247 for model building. Their distribution according to each month and band/index is shown in Figs. 2-3. March and July were the most frequently selected months, followed by June and December with May showing the least consistent value (Fig. 2). The NIR and SWIR bands and the DVI, SAVI, OSAVI were the most stable, with many multispectral indices showing less consistent

251 reflectance values than single bands (Fig. 3).

\subsection{Modelling of reed indicators}

All seven reed indicators were modelled with two bands and six indices issued from three to 256 five scenes (dates), involving subtraction of bands and/or indices between these (Table 3). SAVI 257 and NDWI were the most commonly selected indices, with NIR and SWIR being the only 258 selected bands. DVI was selected for modelling dry- and green-reed density and DVW for 259 modelling reed-cover homogeneity. All these models were accurate when applied to the 2006

260 independent dataset (Table 3, Fig. 4-6). Reed height was particularly easy to predict, as revealed 261 by the high correlation between the predicted and observed values (Fig. 4) and by the numerous 262 significant single- and two-date models that arose during the model selection process. Density of 263 green and dry stems and their ratio showed significantly or nearly significantly different means in 264 2006, suggesting that these parameters might require a field calibration (Table 3, Fig. 5).

265 Actually, a similar reed density can exhibit different spatial patterns from the regular distribution 
266 of shoots to sparsely-distributed dense tussocks, which probably explains the lower predictive 267 power of these models. Reed-cover homogeneity could be accurately and repeatedly predicted, in 268 spite of the low sample size and the fact that these data were originally meant to reflect

269 bathymetric variation rather than vegetation coverage (Fig. 6). Modelling of this parameter 270 would, however, certainly benefit from an increased sampling effort with measurements taken 271 every meter.

\subsection{Model application}

Height of reed stem is a good indicator of stand condition. It is correlated with stem

276 diameter and leaf size (respectively $R=0.82$ and 0.72 , d.f. $=39, P<0.001$ ), as well as flower

277 production and resistance to breakage (van der Toorn \& Mook 1982; Boar, 1992). It evolves

278 rapidly following modifications in water management, especially under brackish conditions. The

279 largest continuous reed area in the Camargue, the Charnier-Scamandre site, is located along a 280 salinity gradient in its northernmost part, with mean underground salinity varying from 27 to 3

$281 \mathrm{~g} / \mathrm{L}$ from west to east (Fig. 7). Mapped reed height in 2005 covaries with this salinity gradient.

282 Predicted reed height ranged from $29 \mathrm{~cm}$ to $309 \mathrm{~cm}$ per pixel, and from 132 to $222 \mathrm{~cm}$ per

283 hydrological unit. Overall, these values were relatively similar in 2006 (respectively 19-309, 117 -

284 220), although some hydrological units exhibited a different pattern between years owing to a

285 different water management (Fig. 7). This spatio-temporal variation in reed height can help orient 286 management options whether in terms of defining optimal hydrological regimes, protecting areas

287 for vulnerable birds (e.g. great reed warbler and purple heron) or selecting areas for reed

288 harvesting. 


\section{Discussion}

We demonstrate that multi-spectral and seasonal imagery can be a powerful tool for monitoring fine-scale variations in reedbed attributes relevant to bird ecology and habitat management. Studies using scenes from multiple dates often rely on a single value (eg: mean reflectance or principal-component axes) for model building (Suárez-Seoane et al., 2002; Wiegand et al., 2008). Monthly subtraction between bands and indices issued from different images associated with specific phenological stages of reed was a key feature of the models developed in this study, allowing these bands and indices to carry a lot more information than 299 what they were originally created for.

Although SPOT-5 scenes were radiometrically corrected, many bands and indices showed

301 inconsistent values between years. Their pre-selection, based on their reliability for describing the 302 selected reed parameters under different environmental and hydrological conditions, appears as a 303 necessary step of model development. For instance, NDVI was stable in July only and was not 304 selected in any of the final models, highlighting the usefulness of exploring the potential of other, 305 less well-known indices. This statement certainly holds for any remote-sensing application in 306 ecological studies that are currently largely restricted to the use of NDVI (Pettorelli et al., 2005).

307 The most useful indices for modelling reed attributes in this study were the SAVI, NDWIs 308 (NDWIF, MNDWI), and DVI for height, diameter and density of green reeds, in addition to MSI

309 for the ratio dry/green reeds and DVW for reed-cover homogeneity. SAVI accounts for the 310 spectral contribution of soil and is recommended for predicting biomass when soil exposure is 311 high relative to vegetation cover (Zhang et al, 1997). This index, designed to eliminate soil312 induced variation, was mostly selected in December and March when vegetation coverage of reed 313 stands is minimal. SAVI was always combined with indices (NDWIs and MSI) or bands 
314 involving the NIR and/or SWIR in our models. These bands provide a pigment-independent

315 quantitative estimate of vegetation water content, and are influenced by leaf structure, leaf dry

316 matter, canopy matter, canopy structure and leaf area index (Ceccato et al, 2002; Cheng et al,

317 2006). DVI has been shown to be a good predictor of deciduous plantations and is considered

318 more sensitive to vegetation density than other indices (Franklin, 2001). In our model, DVI was

319 most useful for predicting density of green and dry stems and their ratio. DWIs and MSI probably

320 reflect dry matter and water content, with the advantage of the NDWI not being saturated during

321 the growing period like other vegetation indices. Gao (1996) suggests that the NDWI, which

322 increases from dry soil to free water, should be used in combination with NDVI. The DVW

323 combines both indices to reinforce the perception of free water bodies (Gond et al, 2004), and is

324 then particularly well-suited to model reed-cover homogeneity which reflects the proportion of

325 open-water areas inside reedbeds.

326 Thorough field campaigns to develop accurate and robust remote-sensing tools that do not

327 require field sampling when re-applied (or limited field work for calibration), is a desirable

328 approach for ecosystem long-term monitoring. Application of the models developed in this study

329 will allow detecting local or regional reedbed degradation in order to orient stakeholders toward

330 more sustainable management practices. In cases of conflicts around the water resource among

331 landowners, users and nature conservationists, they will provide an unbiased source of

332 information to address the impact of various management options for collective-decision making.

333 Combined with models on the ecological requirements of vulnerable-bird species, they have the

334 potential to provide precise estimates of potential species ranges and their evolution in the long

335 term. Human activities are increasing in intensity and extent, ensuing habitat loss and degradation

336 that impair ecosystem function and reduce the value of ecosystem services for humans. The need 
to detect and predict changes in natural ecosystems in general and wetlands in particular has

338 never been greater.

\section{Conclusion}

Our study shows that stand condition of reed marshes can be mapped accurately over a major river delta, providing a powerful and robust monitoring tool for evidence-based habitat

344 management. This study highlights the potentialities of multiseasonal and multi-spectral data in

345 ecological applications. The increased availability of powerful statistical techniques, geographic 346 information systems (GIS) and satellite sensors is opening a new field for monitoring the health 347 of ecosystems across large geographic areas (Guisan \& Zimmermann, 2000; Kerr \& Ostrovsky, 348 2003). The high spatial resolution of SPOT-5 scenes makes it possible to obtain detailed 349 attributes of ecosystem characterization that can be modelled across large spatial extents (Wulder 350 et al., 2005) abolishing the recurrent scale mismatch between field and remotely sensed-data.

\section{Acknowledgements}

We are indebted to the Centre National d'Études Spatiales (CNES) for largely funding the 356 programming and acquisition of SPOT scenes (ISIS Projects 698 \& 795), to the Office National 357 de la Chasse et de la Faune Sauvage (ONCFS) for providing a thesis grant to A. Davranche, and 358 to the Foundation Tour du Valat for logistic support. Thanks are extended to A. Sandoz for his

359 technical advice and to E. Duborper, C. Nourry, A. Diot, J. Desgagné, M. Gobert \& S. Didier, for 360 their contribution to the field work. We are also grateful to the Marais du Vigueirat, commune de 
361 Vauvert, Syndicat Mixte de Camargue Gardoise and the various stakeholders who gave us access 362 to their reed marshes.

\section{References}

Armstrong, J., Armstrong, W., \& van der Putten, W. H. (1996). Phragmites die-back: bud and root death, blockages within the aeration and vascular systems and the possible role of phytotoxins. New Phytologist, 133, 399-414.

Barbraud, C., Lepley, M., Mathevet, R., \& Mauchamp, A. (2002). Reedbed selection and colony size of breeding purple herons Ardea purpurea in Southern France. Ibis, 144, 227-235.

Bedford, A. P. (2005). Decomposition of Phragmites australis litter in seasonally flooded and exposed areas of a managed reedbed. Wetlands, 25, 713-720.

Boar, R. R. (1992). Factors which affect the growth of Phragmites australis. In D. Ward (Ed.), Reedbeds for wildlife (pp. 21-30). Oxford: The Royal Society for the Protection of Birds \& University of Bristol Information Press.

Burgess, N. D., \& Evans, C. E. (1989). The management of reedbeds for birds. Sandy: The Royal Society for the Protection of Birds.

Ceccato, P., Gobron, N., Flasse, S., Pinty, B., \& Tarantola, S. (2002). Designing a spectral index to estimate vegetation water content from remote sensing data: Part 1 - Theoretical approach. Remote Sensing of Environment 82, 188-197.

Chauvelon, P. (2009). Gestion Intégrée d'une Zone humide littorale méditerranéenne aménagée : contraintes, limites et perspectives pour l'Ile de CAMargue (GIZCAM). Programme LITEAU 2, Ministère de l'Ecologie, de l'Energie, du Développement durable et de l'Aménagement du Territoire, Final report, Tour du Valat, 84 pp. 
385 Cheng, Y. B., Zarco-Tejada, P. J., Riano, D., Rueda, C. A., \& Ustin, S. L. (2006). Estimating 386 vegetation water content with hyperspectral data for different canopy scenarios: Relationships between AVIRIS and MODIS indexes. Remote Sensing of Environment 105, 354-366.

388 Clevering, O. A. (1998). Effects of litter accumulation and water table on morphology and 389 productivity of Phragmites australis. Wetlands Ecology and Management, 5, 275-287.

390 Cowie, N. R., Sutherland, W. J., Ditlhogo, M. K. M., \& James, R. (1992). The effects of 391 conservation management of reed beds II. The flora and litter disappearance. Journal of 392 Applied Ecology, 29, 277-284.

393 Davranche, A., Lefebvre, G., \& Poulin, B. (2009a). Radiometric normalization of SPOT 5 scenes: 6S atmospheric model versus pseudo-invariant features. Photogrammetric Engineering and Remote Sensing, 75, 723-728.

396 Davranche, A., Lefebvre, G., \& Poulin, B. (2009b) Wetland monitoring using classification trees and SPOT-5 seasonal time series. Remote Sensing of Environment.

398 Deegan, B. M., White, S. D., \& Ganf, G. G. (2007). The influence of water level fluctuations on 399 the growth of four emergent macrophyte species. Aquatic Botany, 86, 309-315.

400 Dudgeon, D., Arthington, A. H., Gessner, M. O., Kawabata, Z., Knowler, D. J., Lévêque, C., 401 Naiman, R. J., Prieur-Richard, A. H., Soto, D., Stiassny, M. L., \& Sullivan, C. A. (2006). Freshwater biodiversity: importance, threats, status and conservation challenges. Biological Reviews of the Cambridge Philosophical Society, 81, 163-182.

404 Engloner, A. I. (2009). Structure, growth dynamics and biomass of reed (Phragmites australis) $405 \quad$ A review. Flora, 204, 331-346.

406 Franklin, S.E, (2001). Remote sensing for sustainable forest management. Lewis Publishers, New $407 \quad$ York. 
408 Gao, B. G. (1996). NDWI - a normalized difference water index for remote sensing of vegetation 409 liquid water from space. Remote Sensing of Environment, 58, 257-266.

410 Gilbert, G., Tyler, G. A., Dunn, C. J., \& Smith, K. W. (2005). Nesting habitat selection by 411 bitterns Botaurus stellaris in Britain and the implications for wetland management. Biological $412 \quad$ Conservation, 124, 547-553.

413 Gond, V., Bartholome, E., Ouattara, F., Nonguierma, A. \& Bado, L. (2004). Surveillance et 414 cartographie des plans d'eau et des zones humides et inondables en régions arides avec 415 l'instrument VEGETATION embarqué sur SPOT-4. International Journal of Remote 416 Sensing, 25, 987-1004.

417 Granéli, W. (1989). Influence of standing litter on shoot production in reed, Phragmites australis 418 (Cav. Trin. ex Steudel). Aquatic Botany, 35, 99-109.

419 Graveland, J. (1999). Effects of reed cutting on density and breeding success of reed warbler Acrocephalus scirpaceus and sedge warbler Acrocephalus schoenobaenus. Journal of Avian

422 Guisan, A., \& Zimmermann, N. E. (2000). Predictive habitat distribution models in ecology. Ecological Modelling, 135, 147-186.

424 Güsewell, S., \& Klötzli, F. (2000). Assessment of aquatic and terrestrial reed (Phragmites australis) stands. Wetlands Ecology and Management, 8, 367-373.

426 Hanqiu, X. (2006). Modification of Normalized Difference Water Index (NDWI) to enhance open water features in remotely sensed imagery. International Journal of Remote Sensing, 27,

429 Hara, T., van der Toorn, J., \& Mook, J. H. (1993). Growth dynamics and size structure of shoots 430 of Phragmites australis, a clonal plant. Journal of Ecology, 81, 47-60. 
431 Hawke, C. J., \& Jose, P. V. (1996). Reedbed management for commercial and wildlife interests, 432 The Royal Society for the Protection of Birds, Sandy.

433 Huete, A. R. (1988). A Soil-Adjusted Vegetation Index (SAVI). Remote sensing of Environment, $434 \quad 25,295-309$.

435 Hunt, E. R., \& Rock, B. N. (1989). Detection of changes in leaf water content using near- and 436 middle-infrared reflectances. Remote Sensing of Environment, 30, 43-54.

437 Jedraszko-Dabrowska, D. (1992). Reeds as construction supporting great reed warbler 438 (Acrocephalus arundinaceus L.) and reed warbler (Acrocephalus scirpaceus Herm.) nests. $439 \quad$ Ekologia Polska, 39, 229-242.

440 Kerr, J. T., \& Ostrovsky, M. (2003). From space to species: ecological applications for remote $441 \quad$ sensing. Trends in Ecology and Evolution, 18, 299-305.

442 Leisler, B., Ley, H. W., \& Winkler, H. (1989). Habitat, behaviour and morphology of 443 Acrocephalus warblers: An integrated analysis. Ornis Scandinavica, 20, 181-186.

444 Lillesand, T. M., \& Kiefer, R. W. (1987). Remote sensing and image interpretation, 2nd edition. $445 \quad$ John Wiley and Sons, New York.

446 Lissner, J., \& Schierup, H. H. (1997). Effects of salinity on the growth of Phragmites australis. 447 Aquatic Botany, 55, 247-260.

448 Ludwig, D. E., Iannuzzi, T. J., \& Esposito, A. N. (2003). Phragmites and environmental 449 management: a question of values. Estuaries, 26 (2B), 624-630.

450 Mac Nally, R., \& Fleishman, E. (2004) A successful predictive model of species richness using 451 'indicator' species. Conservation Biology, 18, 646-54.

452 Marks, M., Lapin, B., \& Randall, J. (1994). Phragmites australis (P. communis): threats, 453 management, and monitoring. Natural Areas Journal, 14, 285-294. 
Martinez-Vilalta, J., Bertolero, A., Bigas, D., Paquet, J. Y., \& Martinez-Vitalta, A. (2002). Habitat selection of passerine birds nesting in the Ebro Delta reedbeds (NE Spain): management implications. Wetlands, 22, 318-325.

Mathevet, R., Le Page, C., Etienne, M., Lefebvre, G., Poulin, B., Gigot, G., \& Mauchamp, A. (2007). ButorStar: a role-playing game for collective awareness of reedbed wise use. Simulation \& Gaming, 38, 233-262.

Ostendorp, W., Iscli, C., Krauss, M., Krumscheid-Plankert, P., Moret, J. L., Rollier, M., \& Schanz, F. (1995). Lake shore deterioration, reed management and bank restoration in some central European lakes. Ecological Engineering, 5, 51-75.

Pagter, M., Bragato, C., \& Brix, H. (2005). Tolerance and physiological responses of Phragmites australis to water deficit. Aquatic Botany, 81, 285-299.

Pearson, R. L., \& Miller, L. D. (1972). Remote mapping of standing crop biomass for estimation of the productivity of the short-grass Prairie, Pawnee National Grasslands, Colorado. Processing of the 8th International Symposium on Remote Sensing of Environment, ERIM, Ann Arbor, MI, 1357-1381.

Pettorelli, N., Vik, J. O., Mysterud, A., Gaillard, J.-M., Tucker, C. J., \& Stenseth, N. C. (2005). Using the satellite-derived NDVI to assess ecological responses to environmental change. Trends in Ecology and Evolution, 20, 503-510.

Polak, M., Kasprzykowski, Z., \& Kucharczyk, M. (2008). Micro-habitat nest preferences of the great bittern, Botaurus stellaris, on fishponds in central-eastern Poland. Annales Zoologici Fennici, 45, 102-108.

Poulin, B., \& Lefebvre, G. (2002). Effect of winter cutting on the passerine breeding assemblage in French Mediterranean reedbeds. Biodiversity \& Conservation, 11, 1567-1581. 
Poulin, B., Lefebvre, G., \& Mauchamp, A. (2002). Habitat requirements of passerines and reedbed management in southern France. Biological Conservation, 107, 315-325.

Poulin, B., Lefebvre, G., Allard, S., \& Mathevet, R. (2009). Reed harvest and summer drawdown enhance bittern habitat in the Camargue. Biological Conservation, 142, 689-695.

Poulin, B., Lefebvre, G., \& Mathevet, R. (2005). Habitat selection by booming bitterns Botaurus stellaris in French Mediterranean reed-beds. Oryx, 39, 265-274.

Richardson, A. J., \& Everitt, J. H. (1992). Using spectral vegetation indices to estimate rangeland productivity. Geocarto International, 1, 63-69.

Rondeaux, G., Steven, M., \& Baret, F. (1996). Optimization of Soil-Adjusted Vegetation Indices. Remote Sensing of Environment, 55, 95-107.

Rouse, J. W., Haas, R. H., Schell, J. A., \& Deering, D. W. (1973). Monitoring vegetation systems in the great plains with ERTS, Third ERTS Symposium, NASA SP-351, 1, 309-317.

Suárez-Seoane, S., Osborne, P. E., \& Alonso, J. C. (2002). Large-scale habitat selection by agricultural steppe birds in Spain: identifying species-habitat responses using generalised additive models. Journal of Applied Ecology, 39, 755-771.

Thomson, J., Mac Nally, R., Fleishman, E., \& Horrocks, G. (2007). Predicting bird species distributions in reconstructed landscapes. Conservation Biology, 21, 752-66.

Valkamaa, E., Lyytinena, S., \& Koricheva, J. (2008). The impact of reed management on wildlife: a meta-analytical review of European studies. Biological Conservation, 141, 364374.

van der Toorn, J., \& Mook, J. H. (1982). The influence of environmental factors and management on stands of Phragmites australis. I. Effects of burning, frost, and insect damage on shoot density and shoot size. Journal of Applied Ecology, 19, 477-499. 
500 van Deursen, E. J. M., \& Drost, H. J. (1990). Defoliation and treading by cattle of reed $501 \quad$ Phragmites australis. Journal of Applied Ecology, 27, 284-297.

502 Vermote, E., Tanre, D., Deuze, J. L., Herman, M., \& Morcrette, J. J. (1997). Second simulation 503 of the satellite signal in the Solar Spectrum, 6S: An overview. IEEE Transactions on $504 \quad$ Geoscience and Remote Sensing, 35, 675-686.

505 Wiegand, T., Naves, J., Garbulsky, M. F., \& Fernández, N. (2008). Animal habitat quality and 506 ecosystem functioning: exploring seasonal patterns using NDVI. Ecological Monographs, 78, $507 \quad 87-103$.

508 Williams, M. (1993). Wetlands:A Threatened Landscape, Blackwell Publishers, Oxford.

509 Wulder, M. A., Hall, R. J., Coops, N. C., \& Franklin, S. E. (2005). High spatial resolution 510 remotely sensed data for ecosystem characterization. BioScience, 54, 511-521.

511 Zhang, M., Ustin, S. L., Rejmankova, E., \& Sanderson, E. W. (1997). Monitoring Pacific coast 512 salt marshes using remote sensing. Ecological Applications, 7, 1039-1053. 
Table 1

Selected indicators of reed conditions and their relationship (+ or -$)$ with reedbed health, requirements of birds and reed harvesters, and management practices. See text for bird species' abbreviations.

\begin{tabular}{|c|c|c|c|c|c|c|}
\hline \multirow[t]{2}{*}{ Indicator } & \multirow{2}{*}{$\begin{array}{c}\text { Reedbed } \\
\text { health }\end{array}$} & \multicolumn{2}{|c|}{ Ecological needs } & \multicolumn{3}{|c|}{ Ecosystem impacts } \\
\hline & & Bird & Harvester & Cutting & Burning & Grazing \\
\hline Green reed height & + & $+P H$ & + & - & - & - \\
\hline Green reed diameter & + & $+G R W, P H$ & + & + & + & - \\
\hline Green reed density & $+/-$ & $-E B$ & + & + & + & + \\
\hline Dry reed density & - & $+B T$ & - & - & - & - \\
\hline Flower head density & + & $+M W$ & + & - & + & - \\
\hline Ratio dry/green shoots & - & $E B, P H$ & - & - & - & - \\
\hline Reed cover homogeneity & + & $+E B$ & + & & & - \\
\hline Plant richness & - & $+M W$ & - & + & + & + \\
\hline Scrub encroachment & - & & - & - & - & - \\
\hline
\end{tabular}




\section{Table 2}

Multispectral indices used in this study.

\begin{tabular}{|c|c|c|}
\hline Index & Formula & References \\
\hline SR - Simple Ratio & $\mathrm{B} 2 / \mathrm{B} 3$ & Pearson \& Miller, 1972 \\
\hline VI - vegetation index & $\mathrm{B} 3 / \mathrm{B} 2$ & Lillesand \& Kiefer, 1987 \\
\hline DVI - Differential Vegetation Index & B3-B2 & $\begin{array}{l}\text { Richardson \& Everitt, } \\
1992\end{array}$ \\
\hline MSI - Moisture Stress Index & B4/B3 & Hunt \& Rock, 1989 \\
\hline $\begin{array}{l}\text { NDVI - Normalized Difference } \\
\text { Vegetation Index }\end{array}$ & $(\mathrm{B} 3-\mathrm{B} 2) /(\mathrm{B} 3+\mathrm{B} 2)$ & Rouse et al., 1973 \\
\hline $\begin{array}{l}\text { SAVI - Soil Adjusted Vegetation } \\
\text { Index }\end{array}$ & $1.5 *(\mathrm{~B} 3-\mathrm{B} 2) /(\mathrm{B} 3+\mathrm{B} 2+0.5)$ & Huete, 1988 \\
\hline OSAVI - Optimized SAVI & $(\mathrm{B} 3-\mathrm{B} 2) /(\mathrm{B} 3+\mathrm{B} 2+0.16)$ & Rondeaux et. al., 1996 \\
\hline $\begin{array}{l}\text { NDWI - Normalized Difference } \\
\text { Water Index }\end{array}$ & $(\mathrm{B} 3-\mathrm{B} 4) /(\mathrm{B} 3+\mathrm{B} 4)$ & Gao, 1996 \\
\hline $\begin{array}{l}\text { NDWIF - Normalized Difference } \\
\text { Water Index of Mc Feeters }\end{array}$ & $(\mathrm{B} 1-\mathrm{B} 3) /(\mathrm{B} 1+\mathrm{B} 3)$ & Mc Feeters, 1996 \\
\hline $\begin{array}{l}\text { MNDWI - Modified Normalized } \\
\text { Difference Water Index }\end{array}$ & $(\mathrm{B} 1-\mathrm{B} 4) /(\mathrm{B} 1+\mathrm{B} 4)$ & Hanqiu, 2006 \\
\hline $\begin{array}{l}\text { DVW - Difference between } \\
\text { Vegetation and Water }\end{array}$ & NDVI - NDWI & Gond et al, 2004 \\
\hline
\end{tabular}




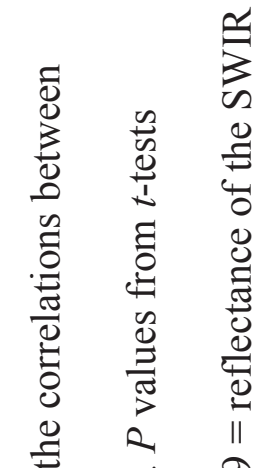

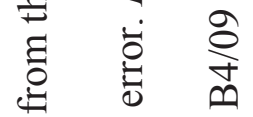

$$
\begin{aligned}
& \text { 总 莺 } \\
& \text { 放 }
\end{aligned}
$$

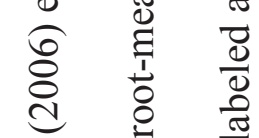

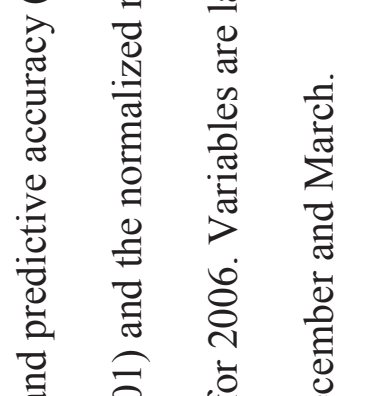

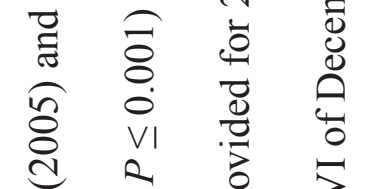

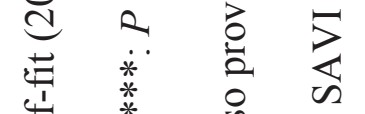

$$
\begin{aligned}
& \text { in }
\end{aligned}
$$

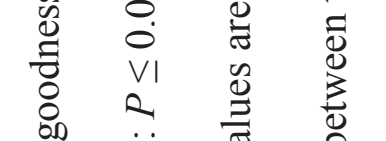

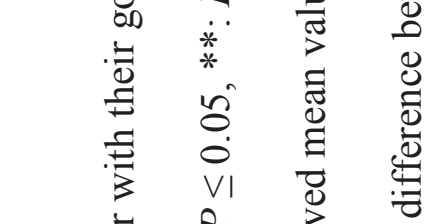

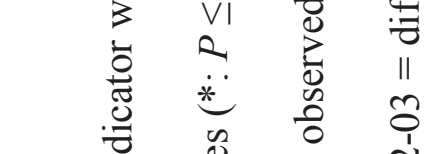

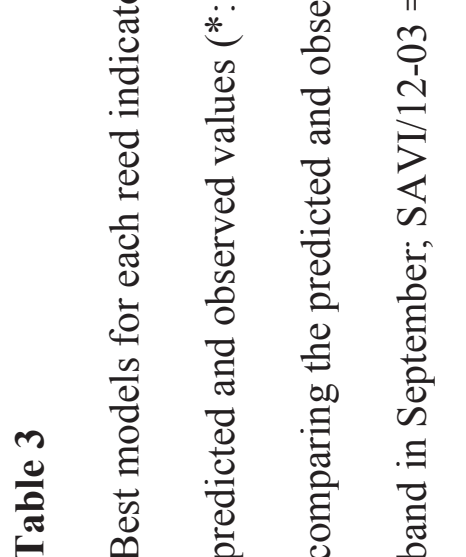

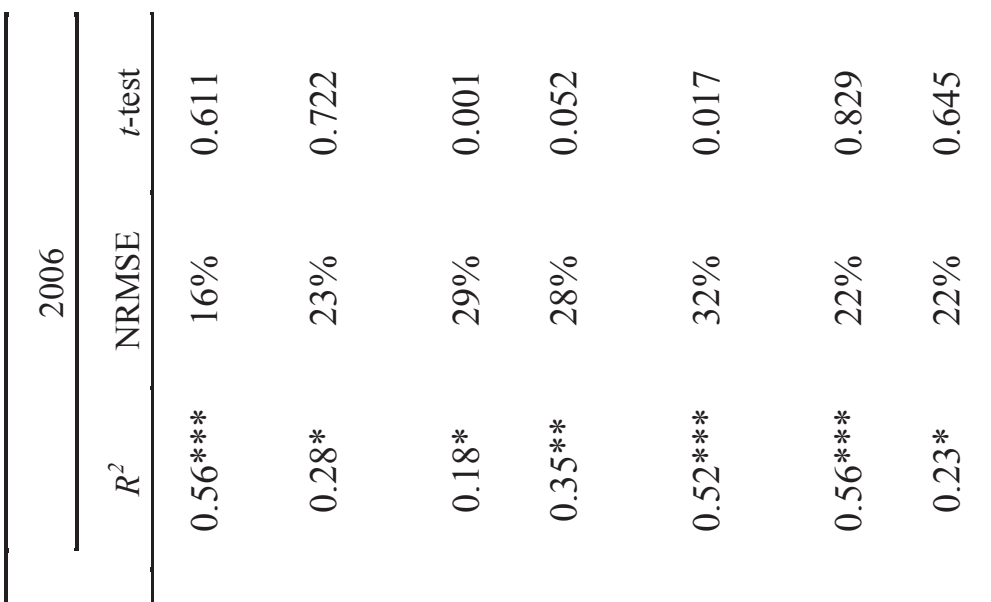

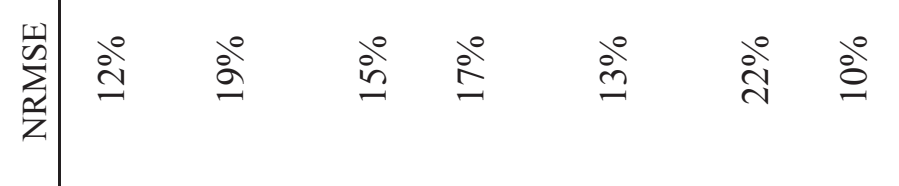

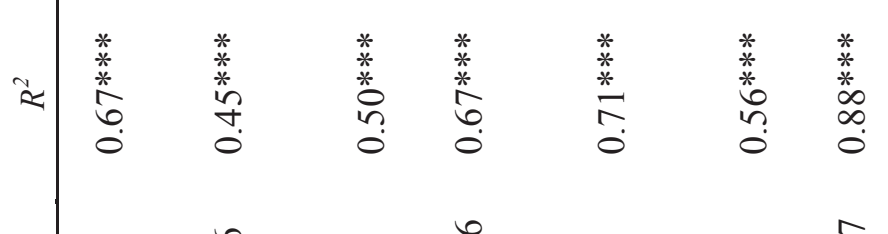

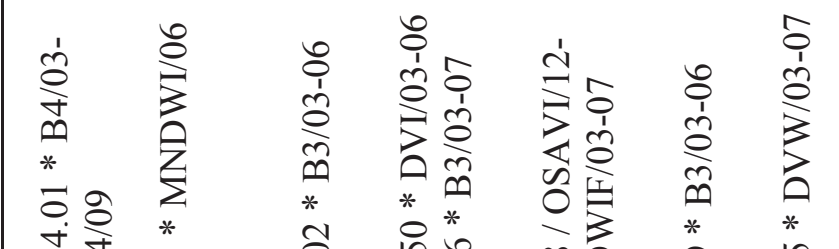

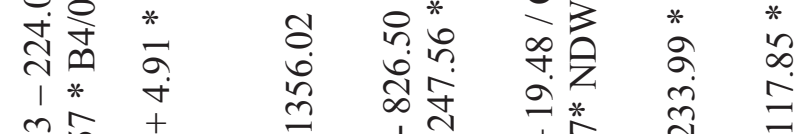

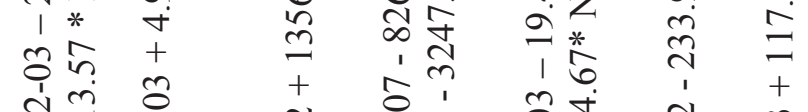

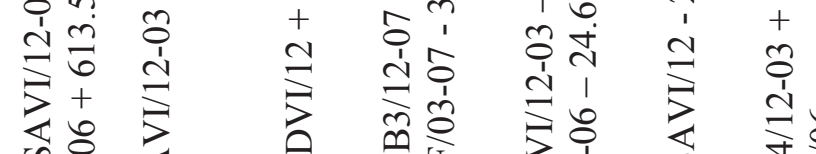

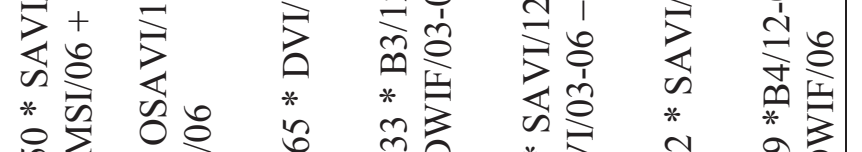

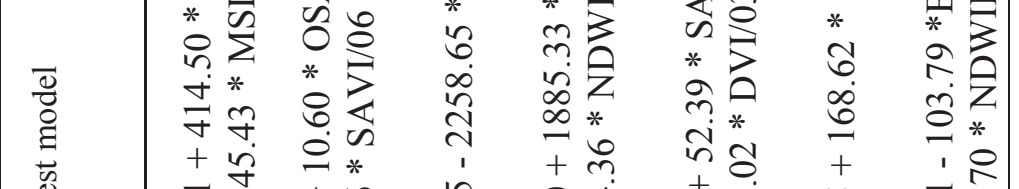

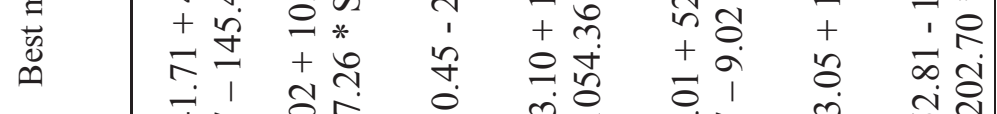

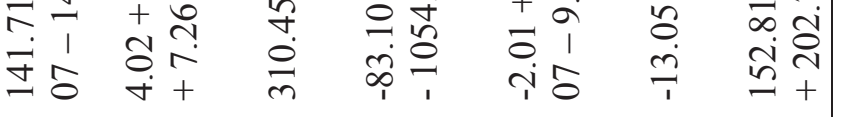

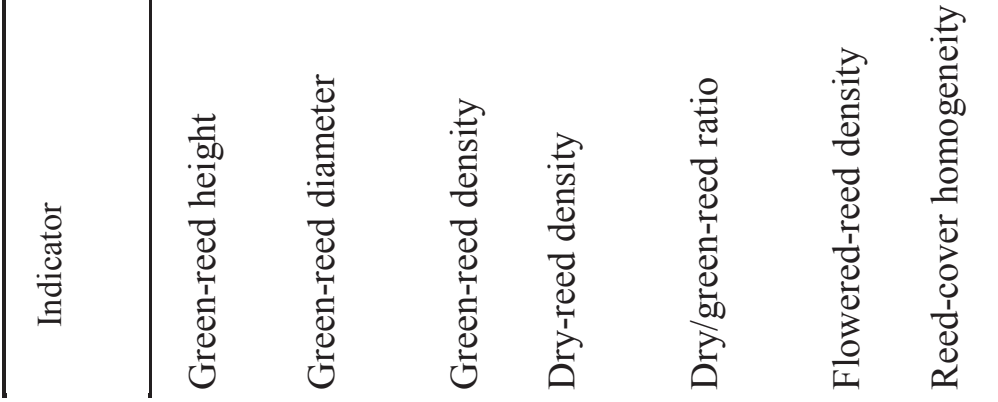




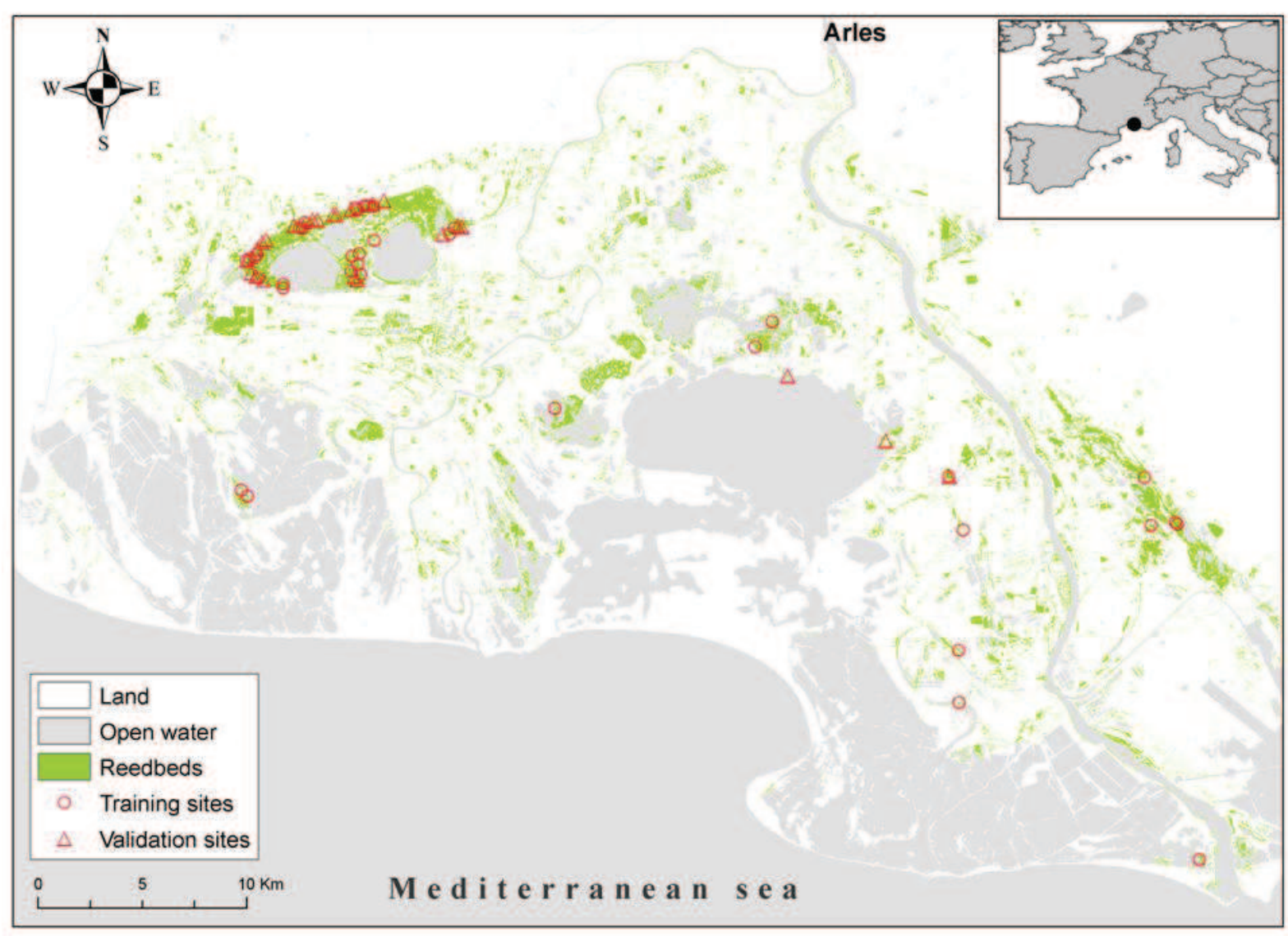

Fig 1. Reedbed distribution in the Camargue with the location of the training (2005) and validation (2006) field plots. 


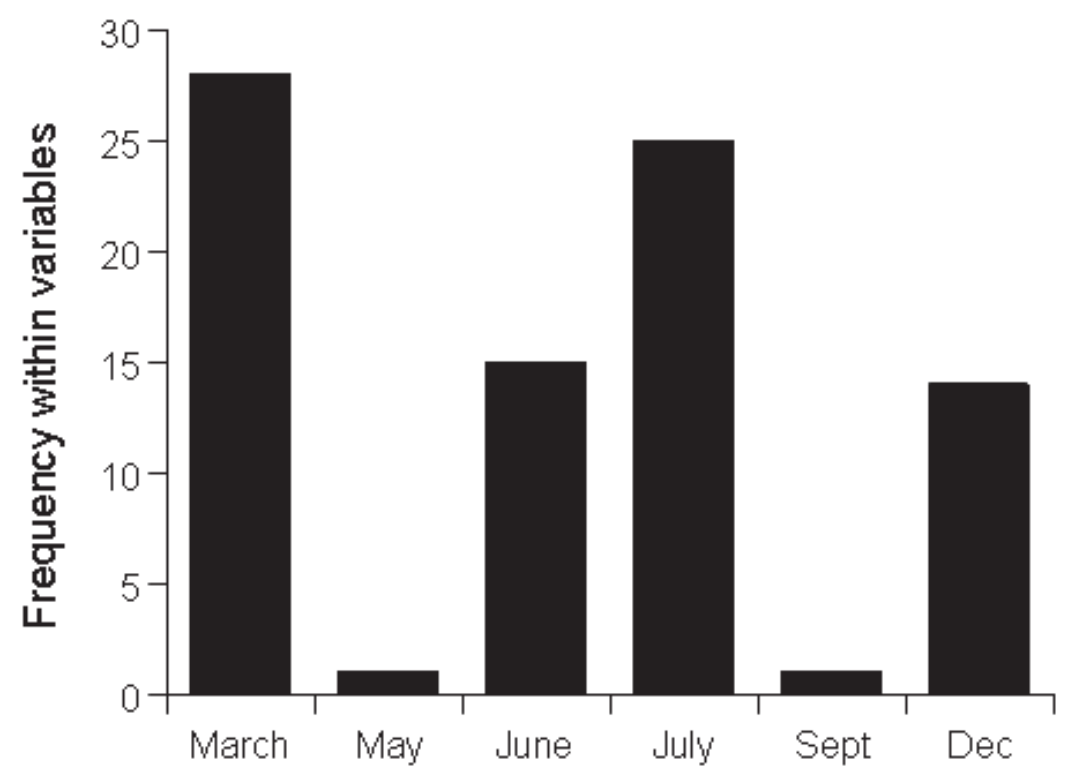

Fig.2. Contribution of each scene to the 53 pre-selected predictive variables. 


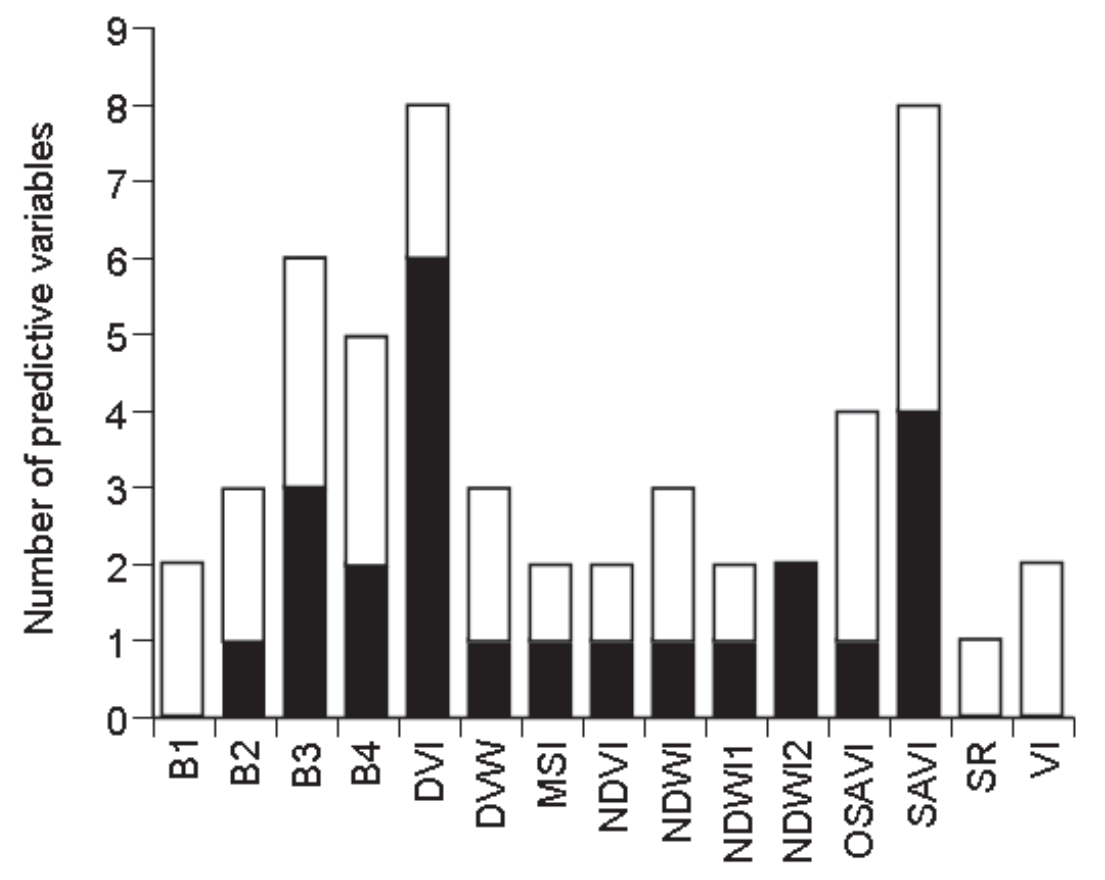

Fig. 3. Contribution of each band and indice to the 53 pre-selected predictive variables. Black columns refers to single-date variables and white columns to two-date variables. 


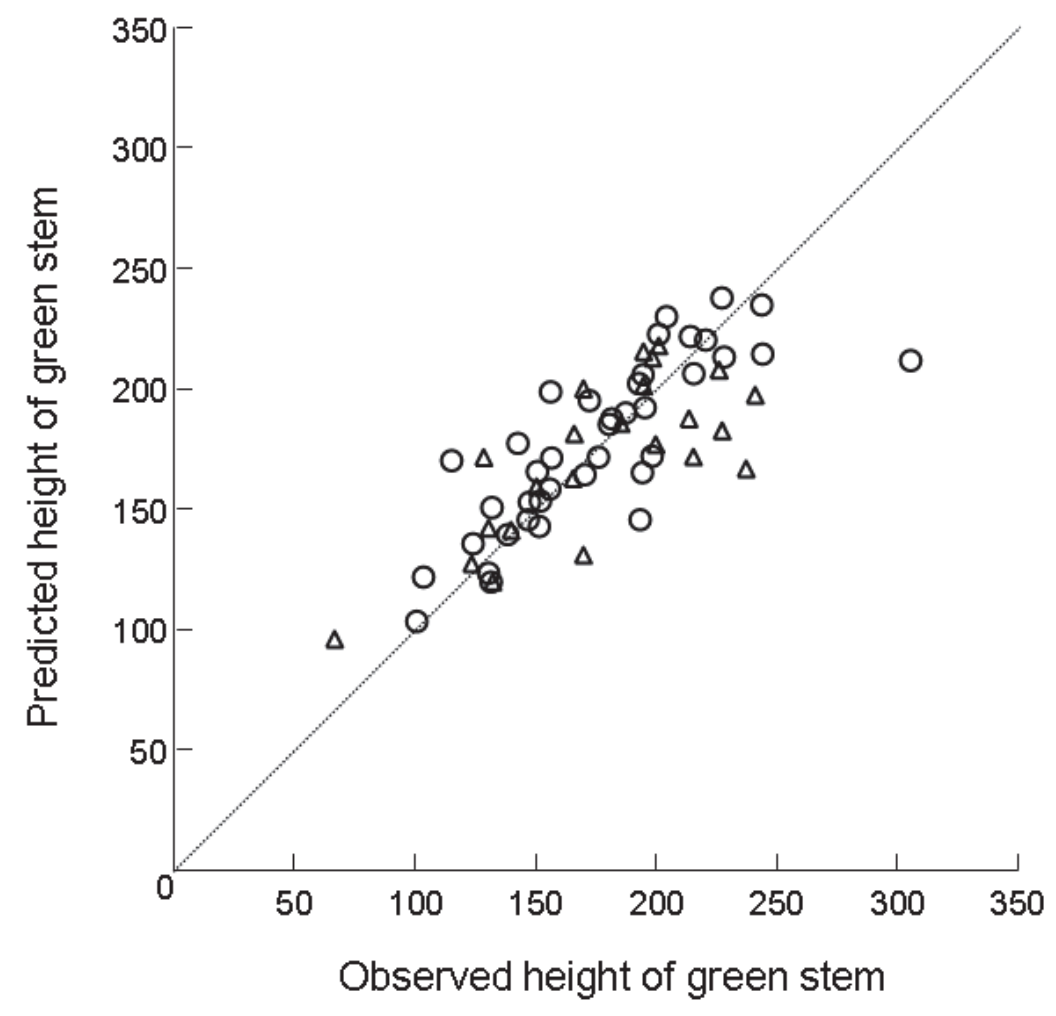

Fig. 4. Correlation between the predicted and observed values for green-stem height in 2005 (o) and $2006(\Delta)$ using the best 2005 model. 


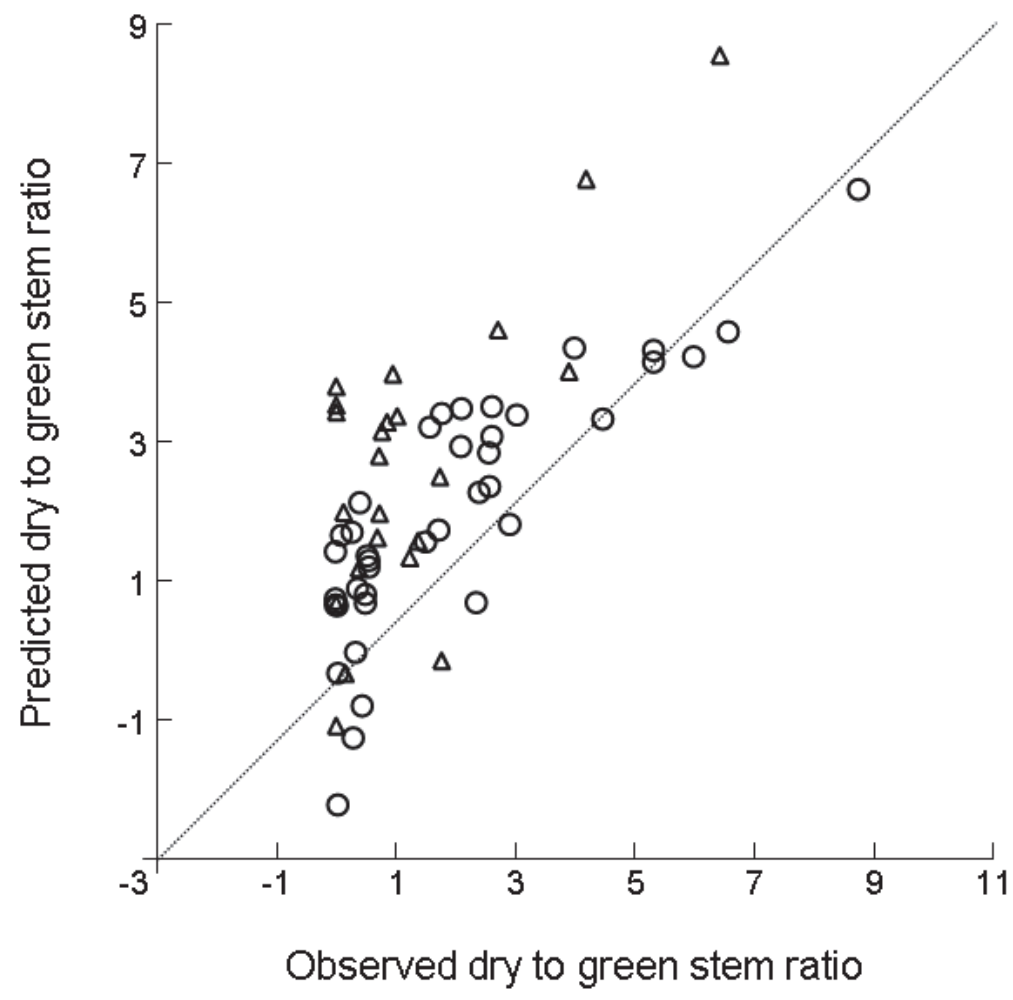

Fig. 5. Correlation between the predicted and observed values for the dry/green-stem ratio in $2005(\mathrm{O})$ and $2006(\Delta)$ using the best 2005 model. 


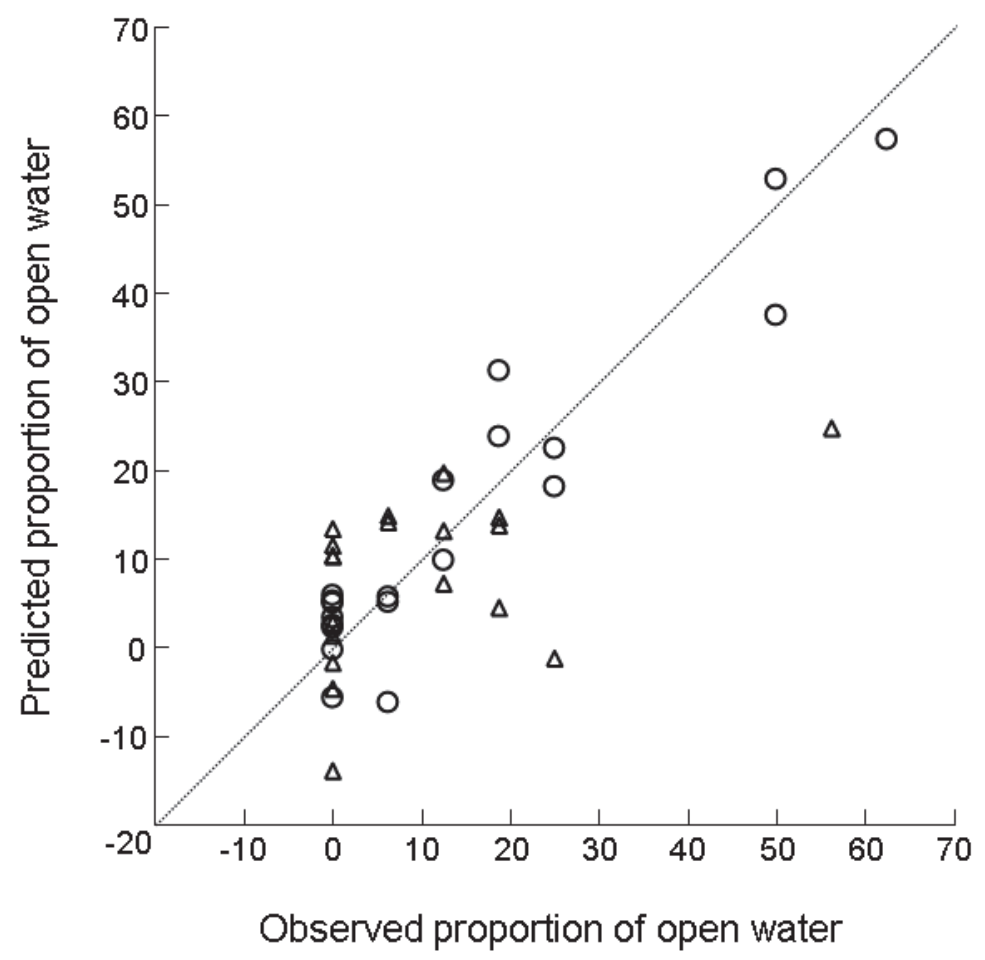

Fig. 6. Correlation between the predicted and observed values for reed-cover heterogeneity in $2005(0)$ and $2006(\Delta)$ using the best 2005 model. 

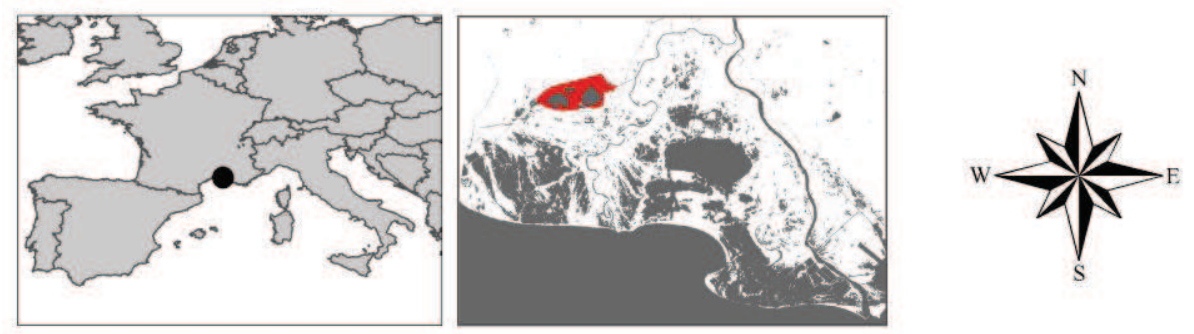

\begin{tabular}{|l|l|}
\hline & Hydrological units \\
\hline & $0-78$ \\
$79-108$ \\
\hline $109-129$ \\
$130-146$ \\
\hline $147-164$ \\
$165-181$ \\
$182-199$ \\
$200-221$ \\
$222-248$ \\
\hline $249-310$ \\
\hline
\end{tabular}
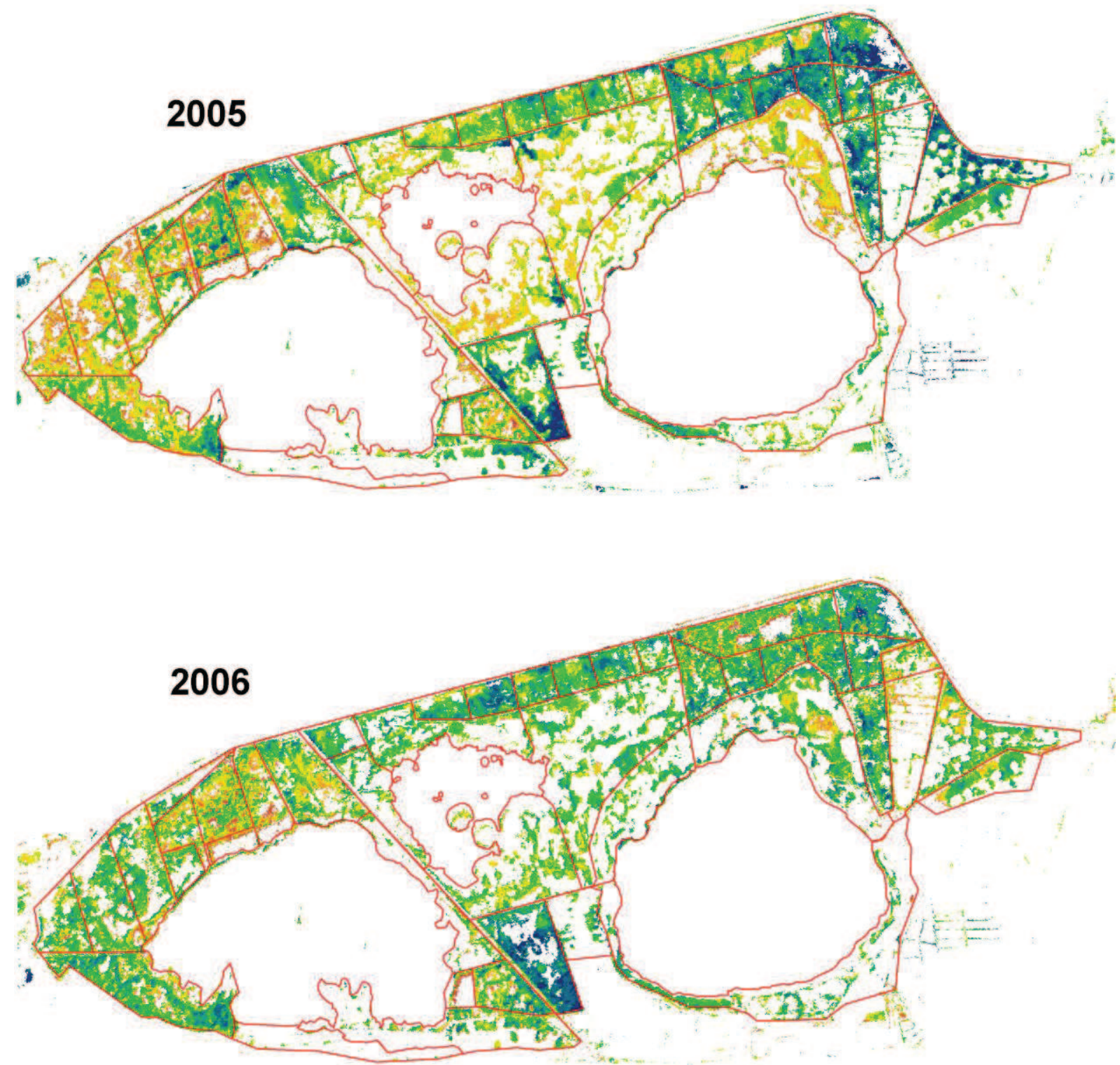

Fig. 7. Mapping of green-reed height (in $\mathrm{cm}$ ) at the Charnier-Scamandre site in 2005 and 2006 using natural breaks for color scheme. Water or land areas free of reed are shown in white. Hydrological units either refer to large water bodies or to embanked reed marshes having independent water management. 